\title{
Comment on Rights and Value: The Committee on Economic, Social and Cultural Rights Addresses the Environment
}

\author{
GIORGIO BARUCHELLO \\ University of Akureyri, Iceland \\ RACHAEL LORNA JOHNSTONE \\ University of Akureyri, Iceland
}

In our 2011 analysis of the International Covenant on Economic, Social and Cultural Rights (ICESCR) and the work of the Committee (ESCR Committee) established to monitor States' compliance under the same, we commented that:

The ICESCR does not address environmental concerns for their own sake. For that reason, the ESCR Committee cannot make broad statements of law or policy on environmental issues but can only address the environment from a strict anthropocentric perspective. In other words, under the ICESCR, the environment has no intrinsic value, but is only valuable to the extent that it maintains or improves humans' abilities to enjoy their economic, social, and cultural rights. As a result, the Committee has no self-standing general comment on the environment or the need for the development required to fulfil economic, social, and cultural rights to be "sustainable." (Baruchello \& Johnstone, 2011, p. 110)

The ESCR Committee has not entirely neglected the environment, as we demonstrated with reference to a number of general comments on housing, health, water, food and education (p. 112), but had not at the time of publication made any statement dedicated to the environment on which humans rely to satisfy their economic, social and cultural rights and the relationship between human rights and environmental concerns. This changed in 2012 when the Committee took the opportunity of the Rio +20 summit to issue the "Statement in the context of the Rio+20 Conference on 'the green economy in the context of sustainable development and poverty eradication"” (ESCR Committee, 2012). This statement was part of a loose 
package of human rights contributions to Rio emerging from the Office of the High Commission on Human Rights (OHCHR, 2012). The Statement is short (just two and a half pages) in contrast to the much lengthier general comments that the Committee is used to producing. It is therefore short on detail and this may have been a deliberate strategy to make it more appealing to busy Rio delegates.

The ESCR Committee demonstrates a genuine concern for the environment and recognizes that the realization of economic, social and cultural rights is dependent upon a healthy environment: one that can provide the necessities of life. Without adequate life support systems, the human rights upheld by the ICESCR and, a fortiori, by the international community as represented by the United Nations (UN), cannot be plausibly attained on a universal scale. By demonstrating such a concern, the ESCR Committee implicitly acknowledges further the foundations of the ICESCR in the life-ground, hence being a token of civil commons, as we discussed in our original 2011 contribution to this journal (pp.103-9).

The ESCR Committee's statement is reminiscent of the earlier environmental declarations of States at Stockholm (1972) and Rio (1992) by refusing to compromise human development. The ESCR Committee cites "sustainable development" eleven times in only two and a half pages of text, including in the title, and sustainable development is indeed the key to its approach. This term came into common use with the Rio Declaration, of which the first principle is: "Human beings are at the centre of concerns for sustainable development. They are entitled to a healthy and productive life in harmony with nature." (Rio Declaration, 1992) A sustainable development approach views environmental protection as integral to, rather than in competition with, development. The Rio Declaration considers the right to development as the key to both human and environmental well-being. This perspective emerges from the negotiations twenty years prior, at Stockholm, during which States had agreed that in developing countries, environmental degradation was in most cases a result of underdevelopment and saw economic development as the key to better environmental conditions (Stockholm Declaration, 1972). With this in mind, the Stockholm Declaration called on developed states to increase financial and technical assistance to developed countries (principle 9).

The ESCR Committee encourages the States at Rio 2012 to integrate a human rights perspective more explicitly into environmental protection and into the final declaration in particular, with increased emphasis on the relationship between the green economy and sustainable development. Human rights and development are not interchangeable; each can lead to the other, but does not necessarily do so. The same considerations apply to sustainable development. Sustainable development, if poorly conceived, can lead to a diminution of human rights, including economic, social and cultural ones. Far from being a purely academic hypothesis, this diminution has been frequently denounced by rights-holding indigenous populations (e.g. Carling, 2012) vis-à-vis the World Bank's self-professed "sustainable development" 
and "green growth" strategies (The World Bank Group, 2011-2) which are currently being reviewed for this very reason (Jim, 2012).

Noting first of all that "many provisions" of the ICESCR "link with environment and sustainable development," the ESCR Committee's statement reminds the States parties of their general comments and other interchanges with States parties through the treaty monitoring process (para 5. The statement then points to the most relevant provisions of the ICESCR and goes beyond the bare text to remind States of circumstances that hinder both sustainable development and human rights fulfilment. These include: a reminder of the provision of article 2(1) that encourages international cooperation to ensure economic, social and cultural rights as well as a call for sustainable development. With this in mind, and repeating many exchanges with States parties through the periodic reporting and monitoring process, the ESCR Committee recommends that States (though not solely developed States) devote $0.7 \%$ of GDP to international development assistance, in conjunction with a human rights approach to development. The position of women is highlighted, both in terms of the positive contributions that they can bring to conservation, use and management of resources as well as their potential vulnerability when the environment becomes degraded. States are reminded of their treaty obligations to provide a healthy working environment. The right to food receives a little more detailed attention, recognizing the obligation to ensure that traditional food sources are not unduly compromised by environmental damage but also to ensure that "green technologies" are not introduced blindly without assessment of adverse impacts on access to food and water. The right to health is addressed and the ESCR Committee underlines the dependency of human health on a healthy environment, pointing to rights to safe water and sanitation and the dangers posed by waste disposal. The right to the highest attainable standard of health is also recognised in light of the opportunities offered by protecting biodiversity for developing pharmaceuticals, but the ESCR Committee reminds States that any exploitation must protect the cultural rights (intellectual property in Western-speak) of indigenous and other local communities. Indigenous and forest dwellers are further considered in light of their inherent rights to the land which they have traditionally used, the need for prior and informed consent to any other economic activities on these lands (such as logging), and the close relationship between these peoples and the habitats in which they live. The destruction of the habitat threatens the very existence of whole communities.

More generally, the ESCR Committee reminds States of the right to development and their responsibility to ensure that development within a State is equitably enjoyed: that "development efforts meet the beneficiaries of development" (para. 6h). States are advised of their responsibility vis á vis private actors (in this case, the corporate sector) to exercise due diligence in regulating and monitoring non-State conduct to ensure that the rights of individuals are not compromised. (This consideration is also highlighted by the High Commissioner for Human Rights, 2012a). Environmental 
impact assessments have long been recognized as an essential element in environmental protection, but the ESCR Committee also urges States to undertake "human rights assessments" of their policies and gives the pertinent example of protecting communities from forced displacement based on ostensible environmental considerations (ESCR Committee 2012, para. 7; and see also High Commissioner for Human Rights, 2012a).

The statement concludes with a summary of four key principles that should be integrated into the Rio +20 outcome document: namely, to reaffirm the Rio Declaration 1992; to reaffirm the human right to development; to link the green economy closely to sustainable development; and to mainstream human rights, especially the rights recognised and endorsed by States parties to the ICESCR.

The ECSR Committee's statement is cautiously worded, but is summed up in more direct and dramatic fashion by the High Commissioner:

\footnotetext{
Human rights matter to this debate [at Rio 2102]. The only way to ensure that the green economy is not a green-washed economy is to insist on a human-rights based approach, putting people and their rights, rather than government power or corporate profit at the centre. In this heavy politicized discussion, human rights are not a regional bargaining chip, but rather a global imperative (p. 4 19 , June a). . . . the difference between a green economy and a green-washed economy is a human-rights based approach (High Commissioner for Human Rights, 2012b, p. 2).
}

The High Commissioner makes explicit that which can only be read between the lines of the ESCR Committee's statement: (a) that ostensibly green measures may inadvertently impact negatively on human rights, but also (b) that, at worst, green measures might be used as a smokescreen to deprive individuals and groups of their basic human rights by, for example, conversion of agricultural land to produce fuel and diversion of rivers from providing basic water supplies and fish to providing energy for corporate profit. Significantly, the ESCR Committee recognizes the symbiotic relationship between some groups living traditionally and the environment in which they live, referring twice to indigenous peoples and the dangers they face from unsustainable destruction of their homes and theft of their traditional knowledge. Whenever alleged development strategies, albeit sustainable or green in name, violate human rights, they fail a basic axiological test: they are no longer universal, for they benefit a group while damaging another. In this respect, they do not count as civil commons as defined and discussed in our previous contribution (Baruchello \& Johnstone, 2011, pp. 97-8).

Moreover, another lesson can be inferred from the fate of the indigenous peoples whose human rights may have been sacrificed to develop, perhaps at times even "sustainably" develop, the nations in which they happen to reside. The lesson is that growth, even of the green kind, can be pursued so that some may benefit at the expense of others. The appropriation of civil commons for class or elite benefit, which we addressed in our previous contribution via reference to John McMurtry's work (p. 98), does 
not need to be confined to the realm of interactions between indigenous and non-indigenous groups. As planet-wide as well as local life support systems shrink in both present and future availability (UN, 2002-12), while income inequality grows between and within countries (UN Development Programme, 2010-2011), the fundamental human needs listed in McMurtry's Well-Being Index (Baruchello \& Johnstone, 2011, p. 105) and addressed by several articles in the ICESCR (ibid, pp.106-8) can be attained by some, but not by all, human beings. Depending on the needs at issue, this partial satisfaction translates into life for some, death for others. Such an outcome may please social Darwinists and devotees of Nietzsche's superman, but human rights legislation is grounded neither in Herbert Spencer's work nor in the philosophy of the author of Also sprach Zarathustra: Ein Buch für Alle und Keinen. Human rights, most certainly economic, social and cultural ones, are not only a matter of securing a better life for all human beings (e.g. labour standards, housing, access to higher education), but also a matter of securing life as such, that is, as opposed to death.

\section{References}

Baruchello, G. \& Johnstone, R. L. (2011). Rights and Value: Construing the International Covenant on Economic, Social and Cultural Rights as Civil Commons. Studies in Social Justice, 5 (1), 91-126.

Carling, J. (2012, June 24). Indigenous Peoples'Letter to the Incoming President of the World Bank. Retrieved from http://www.aippnet.org/home/statement/908-indigenous-peoples-letterto-the-incoming-president-of-the-world-bank.

ESCR Committee. (2012, May 18). Statement in the context of the Rio+20 Conference on "The Green Economy in the Context of Sustainable Development and Poverty Eradication" [Statement adopted by the Committee on Economic, Social and Cultural Rights at its 48th Session, 30 April to 18 May 2012, E/C.12/2012/1] Retrieved from http://www2.ohchr.org/ english/bodies/cescr/statements.htm.

High Commissioner for Human Rights. (2012a, June 19). Statement of High Commissioner for Human Rights Navi Pillay at the OHCHR-UNEP Joint Side Event on Human Rights in Sustainable Development-Human Rights at the Heart of Sustainable Development: Honouring Principle 1. Retrieved from http://www.ohchr.org/EN/NewsEvents/Pages/ DisplayNews.aspx? NewsID $=12255 \&$ LangID $=e$.

High Commissioner for Human Rights. (2012b, June 19). Remarks of High Commissioner for Human Rights Navi Pillay at Rio+social. Retrieved from http://www.ohchr.org/EN/ NewsEvents/Pages/DisplayNews.aspx?NewsID=12254\&LangID=E.

Jim, Y. K. (2012, 6 August). Reply to the Indigenous Peoples 'Letter to the Incoming President of the WorldBank.Retrievedfromhttps://docs.google.com/file/d/0B2Vnefme6P1aUUNKUi1XU3BfUlE/ edit?pli=1.

OHCHR. (2012, 27 September). Office of the High Commissioner for Human Rights, Rio +20 United Nations Conference on Sustainable Development. Retrieved from http://www.ohchr. org/EN/NewsEvents/Rio20/Pages/Statementspeeches.aspx.

Rio Declaration. (1992) on Environment and Development 31 International Legal Materials 876.

Stockholm Declaration. (1972) on the Human Environment 11 International Legal Materials 1416.

The World Bank Group. (2011-2). Sustainable Development [Official Website]. Retrieved from web.worldbank.org http://go.worldbank.org/57GVYJEEN0.

United Nations. (2002-10). Encyclopedia of life support systems. Paris and Oxford: Eolss Publishers. Retrieved from eolss.org http://www.eolss.net.

United Nations Development Programme. (2010-2011). Human Development Reports. Retrieved from hdr.undp.org http://hdr.undp.org/en/reports/. 